\title{
COMMUNICATION ON THE PREVENTION AND TREATMENT OF COVID-19 EPIDEMIC BETWEEN ANHUI PROVINCE OF CHINA AND FEDERAL DISTRICTS ALONG THE VOLGA RIVER IN RUSSIA
}

\author{
CUI WANG, the First Affiliated Hospital of Anhui Medical University, Shushan Qu, Hefei Shi, Anhui Sheng, China \\ MIN SHAO, the First Affiliated Hospital of Anhui Medical University, Shushan Qu, Hefei Shi, Anhui Sheng, China \\ NIAN LIU, the First Affiliated Hospital of Anhui Medical University, Shushan Qu, Hefei Shi, Anhui Sheng, China \\ YUFENG GAO, the First Affiliated Hospital of Anhui Medical University, Shushan Qu, Hefei Shi, Anhui Sheng, China \\ CHANGHUI WANG, the First Affiliated Hospital of Anhui Medical University, Shushan Qu, Hefei Shi, Anhui Sheng, China \\ YUANYUAN YANG, the First Affiliated Hospital of Anhui Medical University, Shushan Qu, Hefei Shi, Anhui Sheng, China \\ MAOHONG BIAN, the First Affiliated Hospital of Anhui Medical University, Shushan Qu, Hefei Shi, Anhui Sheng, China \\ XINGWANG WU, the First Affiliated Hospital of Anhui Medical University, Shushan Qu, Hefei Shi, Anhui Sheng, China \\ PING DING, the First Affiliated Hospital of Anhui Medical University, Shushan Qu, Hefei Shi, Anhui Sheng, China \\ XIAOHU WANG, the First Affiliated Hospital of Anhui Medical University, Shushan Qu, Hefei Shi, Anhui Sheng, China \\ RUI LI, the First Affiliated Hospital of Anhui Medical University, Shushan Qu, Hefei Shi, Anhui Sheng, China \\ GUANGHE FEl, the First Affiliated Hospital of Anhui Medical University, Shushan Qu, Hefei Shi, Anhui Sheng, China, \\ e-mail: verarus@foxmail.com \\ CHAOZHAO LIANG, the First Affiliated Hospital of Anhui Medical University, Shushan Qu, Hefei Shi, Anhui Sheng, China, \\ e-mail:verarus@foxmail.com
}

\begin{abstract}
The ongoing coronavirus infection (COVID-19) pandemic is associated with high rates of morbidity and mortality. Russia, as a transport hub between Europe and Asia, has been hit hard by COVID-19. The aim of this publication is to present the materials of a teleconference held between experts from Anhui province in China and experts from the federal districts of Russia. Material and methods. Discussion of methods of prevention and treatment of the new coronavirus infection COVID-19, as well as issues affecting the immune aspects of the disease, complications and possible long-term follow-up for patients after a new coronavirus infection. Results and discussion. The situation was especially difficult for the federal district along the Volga River, so we shared and discussed questions on the prevention and treatment of the COVID-19 epidemic, which were asked by the experts of the region. Conclusion. The presented article is the result of an online meeting of the doctors from the Volga region of Russia with experts from Anhui province in China. Key words: new coronavirus infection, COVID-19.

For reference: Cui Wang, Min Shao, Nian Liu, Yufeng Gao, Changhui Wang, Yuanyuan Yang, Maohong Bian, Xingwang Wu, Ping Ding, Xiaohu Wang, Rui Li, Guanghe Fei, Chaozhao Liang. Communication on the prevention and treatment of COVID-19 epidemic between Anhui province of China and Federal districts along the Volga river in Russia. The Bulletin of Contemporary Clinical Medicine. 2020; 13 (5): 62-75. DOI: 10.20969/VSKM.2020.13(5).62-75.
\end{abstract}

\section{COVID-19 AND CARDIOVASCULAR SYSTEM}

(1) What is the probability of acute cardiac damage, such as myocarditis, in hospitalized patients with COVID-19?

Literature review indicates that the probability of acute myocardial damage is approximately $7,2-19,7 \%$ for inpatients with COVID-19 [1, 2, 3]. At present, myocardial pathology for a limited number of patients with COVID-19 indicates myocardial interstitium is infiltrated by few monocytes, while no other material damage is discovered in heart tissue. There are cases of myocarditis caused by novel coronavirus infection in adults and children, but the specific incidence of myocarditis caused by 2019-nCoV is still lack of clinical data.

(2) What are diagnostic criteria of myocarditis?

Viral myocarditis (VMC) is generally diagnosed clinically 2019-nCoV infection-induced myocarditis should usually be considered on the basis of clear evidence of 2019-nCoV infections, corresponding clinical manifestations and physical signs, electrocardiogram changes, elevation in myocardial enzymes or troponin, and the evidence of myocardial damage shown by echocardiography and CMR. However, the final diagnosis depends on the myocardial biopsy.

(3) Among patients without potential cardiovascular diseases (COD), what is the percentage of patients who are diagnosed with acute cardiac damage?
According to the literature, approximately $20 \%$ of patients without potential COD (16/78) are diagnosed with acute cardiac damage [4]. Our data show that $24,4 \%(22 / 90)$ of patients are complicated with myocardial damage, and wherein the incidence of myocardial damage for patients without COD is approximately $27,1 \%(13 / 48)$.

(4) What are diagnostic criteria for the occurrence of acute coronary syndrome (ACS) for patients with COVID-19?

Diagnostic criteria of COVID-19 complicated with ACS: (1) Clinical evidence of ACS (typical clinical manifestations, characteristic ECG changes and laboratory findings). (2) COVID-19 confirmed according to Diagnosis and Treatment Plan of the Pneumonia Caused by the Novel Coronavirus (COVID-19) (Version 7, Trial).

(5) How many patients with COVID-19 are observed with cardiac arrhythmia? How does cardiac arrhythmia manifest?

According to the literature, approximately $16,7 \%$ of patients with COVID-19 are complicated with arrhythmia. Among them, the percentage of the patients with critical COVID-19 complicated with arrhythmia is up to $44 \%$, while that of the patients with mild COVID-19 complicated with arrhythmia is approximately $8,7 \%$ [5]. Sinus tachycardia, QT prolongation, atrioventricular 
block and left bundle branch block are common types of arrhythmia. Our clinical data show that the percentage of patients with critical COVID-19 complicated with arrhythmia is approximately $19,6 \%$ (11/56 cases), including1 patient with atrial fibrillation, 1 patient with atrial premature beats, 3 patients with atrioventricular block, 3 patients with incomplete right bundle-branch block, 1 patient with left anterior fascicular block and 1 patient with sinus arrhythmia.

It is found in our study that the serum HDL-C level in severe COVID-19 patients complicated with cardiovascular diseases is significantly lower than that of non-severe COVID-19 patients complicated with the same. HDL-C, an anti-atherosclerotic cholesterol, is the marker of atherosclerosis and one of predictive factors of cardiovascular events. HDL can affect cell surface receptors and immune function cells. A large-scale population cohort study [6] shows that HDL level is related to higher risk of infection, suggesting that HDL also plays an important role in the immune system. This finding indicates that coronary artery-related cardiovascular events could accelerate the progress of COVID-19.

\section{COVID-19 AND RESPIRATORY SYSTEM}

As described in Diagnosis and Treatment Plan of the Pneumonia Caused by the Novel Coronavirus (COVID-19) (Version 7, Trial), the incidence of PPF in common COVID-19 patients is up to $70 \%$; the PPF of the discharged patients with severe COVID-19 can reach $100 \%$; $80 \%$ of the discharged patients still have shortness of breath after doing activities.

In the acute stage, COVID-19 is characterized by multi-leaf and multi-segment ground-glass shadow and patch consolidation shadow, and some lesions are similar to organizing pneumonia (OP)-like changes. Diffuse ground glass shadow can be seen in severe patients. Pathology of cadaveric lung specimens and autopsy pathology all suggest diffuse alveolar damage (DAD). Grid shadow and tractive bronchiectasis can be seen in the recovery period, that is, pulmonary fibrosis changes, and some patients show UIP-like changes.

Early symptoms of CT images of the lung are mainly ground-glass attenuation, exudation, thickening of interlobular septum, etc.; later symptoms are mainly consolidation and bleeding; in the recovery stage, they can be completely absorbed and disappeared, or recovered in the form of fibrosis.

The imaging manifestations in sequelae stage can be represented by fibrosis and lung volume reduction. However, we still lack long-term follow-up results at present. We currently have only 2 months of followup experience, and long-term follow-up results are in progress.

The chest CT of NCP patients is characterised by the onset of bilateral ground-glass lesions located in the subpleural area of the lung, and progressive lesions that result in consolidation with no migratory lesions. Pleural effusions and mediastinal lymphadenopathy are rare. As patients can have inflammatory changes in the lungs alongside a negative early nucleic acid test, chest $\mathrm{CT}$, in combination with epidemiological and laboratory tests, is a useful examination to evaluate the disease and curative effect [7].

When all respiratory symptoms disappeared, the lung consolidation on chest CT images was obviously absorbed, and the throat swabs were negative for SARS-CoV-2 virus by RT-PCR, these patients could resume normal social life. Vast majority of patients have no recurrence of COVID-19. They have no fever, sore throat and dyspnea symptoms. Three-weeks follow-up indicates all cough symptoms disappear and pulmonary lesions are cured on the images. Relevant studies in China demonstrate that only $7,7 \%$ of patients have recurrence in the quarantine phase and observation phase.

A nearly 1-3 months follow up of over 10 patients with COVID-19 in our hospital show that lesions of all patients on CT images of thorax were significantly absorbed (Figure) compared with previous films, not accompanied with fever, diarrhea and any respiratory symptoms.

The majority of patients with COVID-19 only have mild symptoms and even no symptoms. However, once these patients are contracted with serious respiratory failure related to interstitial pneumonia and acute respiratory distress syndrome, they have the highest probability of death. At present, risk factors for respiratory failure include advanced age, complication with basic diseases (e.g., hypertension, diabetes, chronic airway inflammatory disease, etc.), immunosuppression

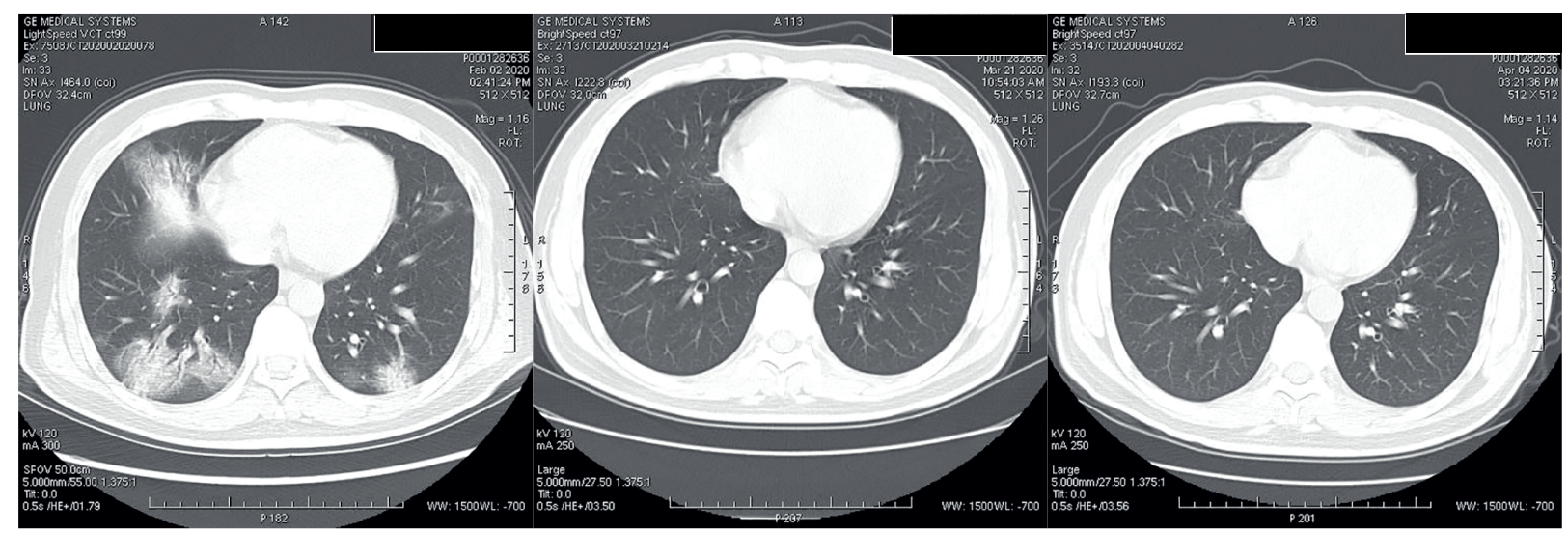

CT of one patient with COVID-19 
and the like; Chinese scholars published that patients with blood type A have a higher incidence of COVID-19 that those of other blood types, while those with blood type O have a lower probability of COVID-19 than those with other blood types. The latest studies from Norway and Germany published in the New England Journal of Medicine (NEJM), a powerful international medical journal, further finds that blood type is also related with the intensity of COVID-19 symptoms. Specifically, COVID-19 patients with blood type A have a higher risk of respiratory failure than those with other blood types; while the same with blood type $O$ have a lower risk of respiratory failure than others. Therefore, blood type $\mathrm{O}$ may have protection functions.

\section{COVID-19 AND THROMBOSIS}

(1) How many COVID-19 patients with pulmonary thromboembolism and deep venous thrombosis detected?

According to the literature, the rate of deep venous thrombosis in lower limbs of COVID-19 is about $46,1 \%$ (66/143 cases) [8]. Recently Chinese scholars have reported the screening and clinical study of deep venous thrombosis in the lower limbs of 48 critical COVID-19 patients in ICU. Among them, 47 patients received anticoagulation treatment through subcutaneous injection of low molecular weight heparin once a day. However, $85,4 \%$ of these patients ( $41 / 48$ cases) still had deep vein thrombosis, of which 36 cases $(75 \%)$ were located in the distal vein and 5 cases $(10,4 \%)$ were located in the proximal vein. Among the dead patients, the percentage of the patients complicated with fulminic pulmonary artery embolism was about $10 \%(8 / 80)$, while that of those with peripheral pulmonary artery embolism was $11,3 \%(9 / 80)$ [9]. For patients in ICU, the incidence of pulmonary artery embolism was approximately $13,6 \%$ $(25 / 184)$ [10].

In a retrospective study of 214 hospitalized COVID-19 patients from Wuhan, China, 5,7\% of severe patients suffered a stroke[11]. A new feature of severe COVID-19 patients is coagulopathy, called "septic-induced coagulopathy» (SIC), with high levels of D-dimer and fibrinogen level. Approximately $50 \%$ of patients are accompanied with increased D-dimer level during disease progression, and the proportion of death is as high as $100 \%$. Increase of D-dimer level in severe patients is an important cause for stroke. Due to lying in bed, obesity, advanced age and thrombophilia and other risk factors, serious patients have a higher probability of stroke caused by hypercoagulable state. Therefore, in the prevention, control and treatment of COVID-19, the link of anticoagulant therapy should not be ignored.

For all severe and critical patients with COVID-19 as well as mild and common patients who have a higher risk by thrombus evaluation, if no contraindications are found, it is recommended to adopt anticoagulant therapy and anticoagulants should be arenteral anticoagulants. For patients with coagulation dysfunction, it is recommended to use unfractionated heparin/ low molecular weight heparin to reduce consumption of feasible anticoagulation therapy by coagulation substrates. Thrombolytic therapy is recommended for patients with clinical acute high-risk pulmonary embolism.
(2) What is the dosage of low molecular weight heparin for inpatients with moderate and severe COVID-19?

It has been reported that among 449 patients with severe COVID-19, low molecular weight heparin injection (40-60mg/day, continuous injection for more than 7 days, 99/449 cases) did not reduce the 28-day mortality of patients, but could effectively improve the sepsis-induced coagulopathy score (SIC score). Recently Chinese scholars have reported the screening and clinical study of deep venous thrombosis in the lower limbs of 48 critical COVID-19 patients in ICU. Among them, 47 patients received anticoagulation treatment through subcutaneous injection of low molecular weight heparin once a day. However, $85,4 \%$ of these patients (41/48 cases) still had deep vein thrombosis, of which 36 cases $(75 \%)$ were located in the distal vein and 5 cases $(10,4 \%)$ were located in the proximal vein. This indicates that further study is needed on the dosage of low molecular weight heparin for moderate and severe COVID-19 patients [12].

\section{IMMUNE STATUS OF PEOPLE AGAINST} COVID-19

After the respiratory system is invaded by COVID-19, patients will present with fever, cough and other symptoms. Then, after receiving enhanced interferon signal under pathological conditions, natural killer cells in human innate immune system are activated, and begin to eliminate virus-infected cells and inhibit the amplification of novel coronavirus. This is the way the human innate immune system works in the early stage (1-4 days). If the patients have a strong immune function, virus amplification can be controlled at this stage, most of them are mild or common patients.

If the innate immune system cannot control such amplification at early stage, then adaptive immune response enables to generate a specific cytotoxic $T$ cell induced by novel coronavirus and kill the cells infected by novel coronavirus. At the same time, B lymphocytes cells are induced by novel coronavirus proteantigen to secrete specific anti-novel coronavirus antibody and eliminate viruses. While viruses are cleared away, the respiratory tract and epithelial tissue of pulmonary alveoli are also damaged. Therefore, pneumonia, respiratory damage and other symptoms occur. The higher the level of virus replication, the more likely it is to cause the immune system to be over-excited, produce "cytokine storm», and easily lead to multiple organ failure.

\section{COVID-19 WITH PREGNANT AND LYING-IN} WOMEN

In the prevention and control of infectious diseases, the two most important links are cutting off transmission route and protecting susceptible population, and pregnant and lying-in women are susceptible population. For this reason, the hospital and each department have taken emergency measures, such as formulating treatment procedures and providing knowledge education for pregnant and lying-in women via media.

No pregnant women with COVID-19 infection had been admitted to our hospital, and no newborns with intrauterine infection have been observed.Available domestic and international evidence suggests that there 
may be no vertical transmission between mother and child.A paper of Academician Qiao Jie published in the New England Journal of Medicine analyzed the clinical characteristics of 118 cases of pregnant and lying-in women infected with COVID-19 in Wuhan, China, among which 68 gave birth to 70 newborns; SARSCoV-2 nucleic acid tests were carried out with throat swabs of 8 newborns and breast milk of 3 cases, and the results were all negative [13]. Another study published in American Journal of Obstetrics and Gynecology summarized reported cases; 48 newborns received nucleic acid test, among which only 2 were positive, and for another 46 pregnant and lying-in women infected with COVID-19, their amniotic fluid, umbilical cord blood, breast milk and throat swab of infants had no COVID-19 virus, but it should not excluded that these confirmed and puerperal women were infected in the later stage of pregnancy, and there's no report on miscarriage of pregnant women infected with COVID-19 in the early stage [14].

Although there is no evidence of vertical transmission through the placenta to the fetus, previous animal studies have shown that viral infections during pregnancy can cause abnormalities in fetal brain and lung development. COCID-19 infection may activate the maternal immune system and then generate a plural number of cytokines, such as IL6 , which, through placental inflammatory response, causes fetal inflammatory response syndrome and further leads to organ damages and potential development defects.

Since the risk of maternal-infant vertical transmission is not clear and pregnancy-related complications caused by COVID-19 are also unknown, we cannot blindly carry out experimental treatment for this special population of pregnant and lying-in women. Clinically, hydroxychloroquine is used to treat recurrent miscarriage (with a dosage of about $300 \mathrm{mg} /$ day), while in antiviral treatment, the minimum dosage is $1000 \mathrm{mg} /$ day, which is much higher than that of other treatments, and chloroquine and its metabolites can pass through the placenta, so it is necessary to consider the dosage when using in pregnant women. In our opinion, it is not recommended to use in pregnant women until COVID-19 light antibody is proved to be safe for antiviral treatment.

6. USING PLASMA FROM CONVALESCENT PATIENTS FOR CRITICAL PATIENTS

(1) When is the best time for critical patients to use plasma from convalescent patients?

For the patients without severe complications and the patients with rapid disease progress, plasma shall be used sooner rather than later.Patients who have not improved after a week of antiviral treatment can get plasma from convalescent patients. The dosage is 200-400 ml/time/day, 2-3 consecutive times for most of patients or a full dosage of $400 \mathrm{mlz}$ for only once.

(2) What laboratory methods can be used to verify the clinical treatment effect of plasma from convalescent patients?

Some laboratory methods can be used to verify the clinical treatment effect of plasma from convalescent patients. Is viral load reduced (if applicable, carry out virus neutralization test)? Is the CT value of virus nucleic acid detection (PCR) increased? Are clinical symptoms relieved? Including: is oxyhemoglobin saturation increased? Does CT scanning indicates that the pulmonary exudation is significantly absorbed.

(3) Questions on plasma donation from convalescent patients.

COVID-19 patients who have been discharged from hospital for 2 weeks (negative in two nucleic acid tests) shall undergo COVID-19 antibody test by a fluorescence kit (provided by WANTAI BioPharm, Beijing), then they can donate plasma. They need to test COVID-19 antibody IgM and total antibody; the titer shall be at least of 1:80. Plasma is collected by plasmapheresis machine and frozen at $-20^{\circ} \mathrm{C}$ for storage. Transfusion is accepted in case of the same blood type or compatibility.

\section{DRUGS THERAPY}

(1) Antibiotic therapy

Patients with mild COVID-19 and common symptoms have relatively lower incidences of secondary bacterial infection, so routine antibiotic therapy is not recommended for use in these patients. In case of continuous fever or fever again after the body temperature becomes normal, routine blood examination should be conducted dynamically; inflammatory marks such as CRP, PCT shall be checked and CT scan of lungs should be done. If there is any evidence of secondary infection, antibiotics can be added, which can be used alone. Drugs covering negative bacteria are preferred.

The severe or critical COVID-19 patients are prone to the secondary bacterial infection with the prolonged hospitalization time, disordered immune system, and early use of hormones to block cytokine storms. For these patients, routine blood examination, inflammatory mark tests, such as CRP, PCT, G test and GM test, and CT scan of lungs should be frequently conducted. If there is any evidence of secondary infection, antibiotics can be added. At the beginning, more powerful drugs covering negative bacteria can be used alone, and those with poor effect or with severe disease can be combined with positive bacteria drugs. Antifungal drugs can be combined when there is evidence and manifestation of fungal infection.

Antibiotic therapy or prevention is not recommended for the mild COVID-19 patients. It is suggested that antibiotics shall not be used for the suspected or confirmed moderate COVID-19 patients unless they are clinically suspected of bacterial infection. It should be noted that severe patients often have a disease course of more than 5-7 days, and there are many manifestations of cellular immunity suppression, especially those who need invasive mechanical ventilation in ICU, and need to pay attention to secondary bacterial or fungal infection. If permitted, respiratory pathogens should be monitored, and specific antiinfective therapy should be performed. If the patients have a history of antibiotics application shorter than 90 days, or have been stayed in hospital for over 72 hours or have suffered from previous structural pulmonary disease, antibiotics that cover drug-resistance bacteria are recommended for use. 
(2) When is it more reasonable to prescribe antimalarial drugs to patients?

The effect of chloroquine in clinical treatment of COVID-19 is still controversial [15]. A prospective study was performed in 30 Chinese patients [16]. These patients were randomized into hydroxychloroquine+standard treatment group (including supportive care, interferon and other antiviral drugs) and standard treatment group (1:1). The hydroxychloroquine+standard treatment group was given $400 \mathrm{mg}$ hydroxychloroquine every day lasting for 5 days; the results showed that there was no statistical difference in virological clearance between these two groups.

In May 2020, NEJM issued the result of a large sample observational study - Observational Study of Hydroxychloroquine in Hospitalized Patients with COVID-19 [17]. Researchers investigated the correlation between COVID-19 patients receiving hydroxychloroquine treatment and intubation or death in a large medical center in New York. Among 1,376 patients included in this study, 346 patients $(25,1 \%)$ suffered from respiratory failure, of which 180 cases were intubated and 166 cases died (without intubation). In the rough analysis, patients who took hydroxychloroquine were more likely to have the main end point event than those who did not. Multiple factor analysis based on propensity score showed that there was no significant correlation between taking hydroxychloroquine and compound end point. Also, there was no significant correlation between azithromycin and compound endpoint.

(3) What means and drugs are effective in treating severe and critical patients?

In the COVID-19 epidemic in China, no drugs with clear antiviral effect can promote virus clearance. In the clinical treatment, abidor, chloroquine/hydroxychloroquine were used orally and interferon was inhaled by atomization. Chinese data partially showed that early warning and short-term application of lowdose hormone for critical patients could decrease the percentage of critical cases and reduce the fatality rate. Patients who have progressed into critical stage are given the plasma from those recovered and accept blood purification treatment and immunotherapy based on routine treatment. These therapies are effective to some extent but there is no prospective randomized controlled study to confirm them. A large-scale clinical trial in Britain has demonstrated that the use of glucocorticoids could reduce the mortality of COVID-19 [18]. In the RECOVERY Study, more than 11,000 patients were recruited from 175 hospitals affiliated to the National Health Service System. Preliminary data indicate that 2,100 subjects recruited from March to June were administrated medium-to-low-dose (6 mg) dexamethasone for consecutive ten days. The treatment outcomes were compared with those of 4,300 patients who underwent the standard nursing against COVID-19 infection. The results show that dexamethasone has the best outcomes for severe patients who need to use the ventilator since the mortality is reduced by $1 / 3$; those who need oxygen inhalation rather than the ventilator are improved after medications, and their mortality risk decreases by $20 \%$.

Although arbidol has been extensively applied during the COVID-19 epidemic in China. There is no clear randomized controlled trial to verify its efficacy. A non-randomized study on 67 COVID-19 patients showed that abidol treatment with a median course of 9-day treatment was associated with lower mortality and higher discharge rate compared with patients who did not use the drug [19]. However, this data cannot determine the efficacy of arbidol against COVID-19. RCT should be performed to further evaluate this drug.Oseltamivir, a neuraminidase inhibitor, has been approved for use in the treatment of influenza, but no reports have been found on the anti-SARS-CoV-2 activity in vitro. Therefore, it is not suggested to consider it an recommended intervention measure. Once influenza is excluded, this drug may have no actions in the treatment of COVID-19.

\section{(4) Anti-interleukin drugs in the treatment}

According to Guidelines of Diagnosis and Treatment of COVID-19 in China (7th Edition): Kang-IL drugs are mainly used to inhibit the cytokine storm. At present, Kang IL-6 therapy is more often used clinically in China. Taking Tocilizumab for example, it is suitable for the treatment of patients with extensive lesions in lungs and critical patients. Besides, Tocilizumab can be used for the treatment of the patients with increased IL-6 level shown in laboratory test. Direction for use: the first dosage is $4-8 \mathrm{mg} / \mathrm{kg}$, the recommended dosage is $400 \mathrm{mg}$, diluted to $100 \mathrm{ml}$ by $0,9 \%$ normal saline. Transfusion shall last for more than 1 hour. The maximum single dosage shall not exceed $800 \mathrm{mg}$, and attention shall be paid to allergic reaction.

(5) Systematic use of corticosteroids

Related studies have shown that systemic glucocorticoid shall not be routinely used to treat viral pneumonia. A systematic review and meta-analysis of the effects of glucocorticoid treatment on the prognosis of SARS-CoV-2, SARS-CoV and MERS-CoV patients showed that glucocorticoid did not significantly reduce the risk of death, the hospitalization time, the hospitalization rate in ICU and the use of mechanical ventilation. A systematic review of an observational study on the use of corticosteroids in SARS patients reported no survival benefits and possible hazards (avascular necrosis of femoral head, diabetes and delayed virus clearance). A systematic review of observational studies on influenza showed that the mortality and the risk of secondary infection were higher when corticosteroids were used. Patients with acute exacerbation of chronic obstructive pulmonary disease (AECOPD) need to use glucocorticoids appropriately according to their specific symptoms.

Diagnosis and Treatment Plan of Severe and Critical COVID-19 Cases (Trial, 2nd Edition): at present, there is no evidence-based medical proof to support the application of glucocorticoid to improve the treatment of COVID-19. However, for patients with progressive deterioration of oxygenation index, rapid imaging progress and excessive activation 
of inflammatory reaction, methylprednisolone is considered for short-term treatment (40 mg, q12h, for 5 days). Before that, contraindications for hormones should be analyzed. In the process, the changes in blood pressure and blood glucose of patients shall be closely monitored.

\section{SEQUELAE OF COVID-19}

Damage to the lungs: It is mainly manifested as shortness of breath when walking at fast pace, unable to exercise normally, and even unable to return to the previous work. Some of severe patients may have pulmonary fibrosis after being cured, which may restrict their daily life. At present, there are no specific medicines to treat pulmonary fibrosis, and the condition is irreversible.

Damage to liver and kidney: Studies have pointed out that kidney damage is common among COVID-19 infected people.

Damage to the brain: Many patients who recover suffer very severe central nervous sequelae. There are mainly three types of symptoms: 1) Central nervous system symptoms, such as headache, dizziness, disturbance of consciousness, acute cerebrovascular disease, epilepsy. etc. 2) Peripheral nervous system symptoms, such as hypogeusia, hyposmia, anorexia, neuralgia, etc. 3) Muscle injury. Besides, many asymptomatic carriers have sequela like thrombosis getting into blood vessel of brain, which eventually cause a stroke.

Damage to the heart: Researchers find that in a survey of 8000 patients infected with COVID-19, more than a half of critically ill patients suffered from cardiac trauma and some of them even died. Especially for COVID-19 patients who have used a ventilator, the complications are more serious.

Reduction of lifespan: According to a study led by a Scottish scholar, critically ill patients infected with COVID-19 are expected to lose an average of 14 and 12 years of life after cure due to the attacks of the Virus on various organs; the lifespan reduced due to COVID-19 is similar to that of severe diseases such as heart disease or severe respiratory disease. Of course, this study, though questioned by many researchers, suggests that the sequelae of COVID-19 may be more serious than we have thought.

9. COVID-19. CONTROL AND PREVENTION INFECTION MANAGEMENT AND PREVENTION EXPERIENCE OF HOSPITAL

COVID-19 Control and Prevention - Infection Management and Prevention Experience of Hospital are based on the principle of «isolating infection source, cutting off transmission route and protecting the susceptible population». The main transmission routes of COVID-19 are respiratory droplet and contact transmission. There is possibility of aerosol transmission (closed environment, long time, high concentration). Since COVID-19 can be detected from feces and urine, attention should be paid to aerosol or contact transmission under environmental pollution caused by feces and urine.Other transmission routes remain to be clarified. The infection source is mainly patients infected with COVID-19. Asymptomatic carrier can also be an infection source. People are generally susceptible.

It is found that the virus can survive for 3 hours in aerosol (under a temperature of $21-23^{\circ} \mathrm{C}$ and relative humidity of $65 \%$ ). It can survive for at least 4 hours on copper surface. It can survive for 24 hours on carton surface. It can survive for 2-3 days on stainless steel and plastic surfaces (under a temperature of $21-23^{\circ} \mathrm{C}$ and relative humidity of $40 \%$ ).COVID-19 is sensitive to ultraviolet and heat, and can be effectively inactivated by $56^{\circ} \mathrm{C} 30 \mathrm{~min}$, diethyl ether, $75 \%$ ethyl alcohol, chlorine-containing disinfectant, peracetic acid and chloroform.

COVID-19 Diagnosis and Treatment Plan of our country has been revised seven times. Combined with currently known etiological characteristics of COVID-19 and improved on the basis of existing systems, standards and norms for infection prevention and control in medical institutions, the Technical Guide emphasizes more on practice and guidance. Due to strict compliance with the Technical Guide, more than 42,000 medical staff supporting Wuhan nationwide were free from infection. The Technical Guide includes four aspects: I. Basic Requirements. II. Management of Key Departments. III. Protection of Medical Staff. IV. Strengthen Management of Patients. Basic Requirements include emergency plan and work flow formulating, training for all workers and staff, protection of medical staff, health care for medical personnel, enhanced surveillance for infection, management of cleaning and disinfection, management and education of patients, management of infection outbreak and medical waste. Management of Key Departments include fever clinic and outpatient, emergency treatment, Inpatient ward (room) for admission and treatment of suspected or confirmed patients and General ward. Medical Staff take droplet isolation, contact isolation and air isolation protection measures to achieve different protection according to different situations. While paying attention to the management of patients and medical staff, the hospital should scientifically and reasonably formulate a screening process for all kinds of personnel according to the working conditions of other different personnel, so as to prevent all kinds of personnel from becoming the source of imported infection.

Transparency of the study. The study did not have sponsorship. The authors are solely responsible for the provision of the final version of the manuscript for publication.

Declaration of financial or other relationships. All authors participated in the conception and design of the study and in the writing of the manuscript. The final version of the manuscript was approved by all the authors. The authors did not receive a fee for the study. 


\title{
ОБМЕН ИНФОРМАЦИЕЙ О ПРОФИЛАКТИКЕ И ЛЕЧЕНИИ НОВОЙ КОРОНАВИРУСНОЙ ИНФЕКЦИИ COVID-19 МЕЖДУ ПРОВИНЦИЕЙ АНЬХОЙ В КИТАЕ И ФЕДЕРАЛЬНЫМИ ОКРУГАМИ ВДОЛЬ РЕКИ ВОЛГИ В РОССИИ: ИТОГИ ТЕЛЕКОНФЕРЕНЦИИ (пер. с ангЛ. - Визель Александр Андреевич,
} докт. мед. наук, профессор, зав. кафедрой фтизиопульмонологии ФГБОУ ВО Казанский ГМУ Минздрава России)

\begin{abstract}
цУй ВАН, Первая дочерняя больница Аньхойского медицинского университета, Хэфэй, Китай Минь ШАО, Первая дочерняя больница Аньхойского медицинского университета, Хэфэй, Китай нянь лю, Первая дочерняя больница Аньхойского медицинского университета, Хэфэй, Китай ЮЙФЭН ГАО, Первая дочерняя больница Аньхойского медицинского университета, Хэфэй, Китай ЧАНХУЭЙ вАН, Первая дочерняя больница Аньхойского медицинского университета, Хэфэй, Китай ЮАНЬЮАНЬ ЯН, Первая дочерняя больница Аньхойского медицинского университета, Хэфэй, Китай МАОХУН Бянь, Первая дочерняя больница Аньхойского медицинского университета, Хэфэй, Китай СинвАН ВУ, Первая дочерняя больница Аньхойского медицинского университета, Хэфэй, Китай пин дин, Первая дочерняя больница Аньхойского медицинского университета, Хэфэй, Китай СяОхУ ВАН, Первая дочерняя больница Аньхойского медицинского университета, Хэфэй, Китай Руи ли, Первая дочерняя больница Аньхойского медицинского университета, Хэфэй, Китай ГУАНХЭ ФЭЙ, Первая дочерняя больница Аньхойского медицинского университета, Хэфэй, Китай чАОчЖАО ЛЯн, Первая дочерняя больница Аньхойского медицинского университета, Хэфэй, Китай
\end{abstract}

\begin{abstract}
Реферат. Продолжающаяся пандемия коронавирусной инфекции (COVID-19) связана с высокими показателями заболеваемости и смертности. Россия как транспортный узел между Европой и Азией сильно пострадала от COVID-19. Цель данной публикации - представить материалы телеконференции, которая прошла между экспертами провинции Аньхой в Китае и экспертами федеральных округов России. Материал и методы. Обсуждение методов профилактики и лечения новой коронавирусной инфекции COVID-19, а также вопросов, затрагивающих иммунные аспекты заболевания, осложнения и возможный отдаленный катамнез для пациентов после перенесенной новой коронавирусной инфекции. Результаты и их обсуждение. Особенно тяжелая ситуация сложилась в Приволжском федеральном округе, поэтому обсуждались вопросы по профилактике и лечению эпидемии COVID-19, заданные нам экспертами региона. Выводы (дополнены от лица переводчика). Представленная статья является итогом онлайн встречи врачей Поволжского региона России со специалистами провинции Аньхой в Китае. На тот момент (2 июля 2020 г.) нам было важно услышать коллег. Прошло почти 3 мес, и мы должны понимать, что изложенные здесь положения уже не могут быть руководством к действию это опыт соседней страны на тот момент. Мы, в России, должны ориентироваться на последнюю версию Федеральных временных клинических рекомендаций, которые отражают текущий момент и те перемены, которые происходят сейчас очень быстро.

Ключевые слова: новая коронавирусная инфекция, COVID-19.

Для ссылки: Обмен информацией о профилактике и лечении новой коронавирусной инфекции COVID-19 между провинцией Аньхой в Китае и федеральными округами вдоль реки Волги в России: итоги телеконференции / Цуй Ван, Минь Шао, Нянь Лю [и др.] // Вестник современной клинической медицины. - 2020. - Т. 13, вып. 5. C.62-75. DOI: 10.20969/VSKM.2020.13(5).62-75.
\end{abstract}

\section{COVID-19 И СЕРДЕЧНО-СОСУДИСТАЯ СИСТЕMA}

1.1. Какова вероятность острого сердечного поражения, такого как миокардит, у госпитализированных пациентов c COVID-19?

Обзор литературы показывает, что вероятность острого повреждения миокарда составляет примерно 7,2-19,7\% для стационарных пациентов c COVID-19 [1, 2, 3]. В настоящее время патология миокарда у ограниченного числа пациентов с COVID-19 указывает на инфильтрацию интерстиция миокарда немногочисленными моноцитами, в то время как других материальных повреждений сердечной ткани не обнаружено. Есть случаи миокардита, вызванного новой коронавирусной инфекцией, у взрослых и детей, но о конкретной частоте миокардита, вызванного COVID-19, до сих пор клинических данных нет.

1.2. Каковы диагностические критерии миокардита?
Вирусный миокардит (ВМК) обычно диагностируется клинически. Миокардит, вызванный инфекцией 2019-nCoV, обычно следует рассматривать на основе четких доказательств инфекции 2019-nCoV, соответствующих клинических проявлений и фиизических признаков, изменений электрокардиограммы, повышения уровня ферментов миокарда или тропонина и доказательства повреждения миокарда, основанные на данных эхокардиографиии и МРТ сердца. Однако окончательный диагноз зависит от биопсии миокарда.

1.3. Каков процент пациентов без потенциальных сердечно-сосудистых заболеваний, у которых диагностировано острое сердечное поражение?

Согласно литературным данным, примерно у $20 \%$ пациентов без потенциальной патологии сердца (16/78) диагностируется острое сердечное поражение [4]. Наши данные показывают, что $24,4 \%$ (22/90) пациентов имеют осложнения, связанные с 
поражением миокарда, и при этом частота поражения миокарда у пациентов без предшествующей патологии сердца составляет примерно 27,1\% (13/48).

1.4. Каковы диагностические критерии возникновения острого коронарного синдрома у пациентов с COVID-19?

Диагностические критерии COVID-19, осложненного острым коронарным синдромом (ОКС):

- Клинические признаки ОКС (типичные клинические проявления, характерные изменения ЭКГ и лабораторные данные).

- COVID-19 подтвержден в соответствии с планом диагностики и лечения пневмонии, вызванной новым коронавирусом (COVID-19) (версия 7, испытательная).

1.5. Сколько пациентов с COVID-19 наблюдаются с сердечной аритмией? Как проявляется сердечная аритмия?

По данным литературы, примерно у 16,7\% пациентов с COVID-19 наблюдается аритмия. Среди них процент пациентов с критическим COVID-19, осложненным аритмией, составляет до 44\%, тогда как процент пациентов с легкой формой COVID-19, осложненной аритмией, составляет примерно 8,7\% [5]. Синусовая тахикардия, удлинение интервала QT, атриовентрикулярная блокада и блокада левой ножки пучка Гиса - распространенные типы нарушений. Наши клинические данные показывают, что процент пациентов с критическим COVID-19, осложненным аритмией, составляет примерно 19,6\% (11/56 случаев), в том числе 1 пациент с фрибрилляцией предсердий, 1 пациент с преждевременными сокращениями предсердий, 3 пациента с атриовентрикулярной блокадой, 3 пациента с неполной блокадой правой ножки пучка Гиса, 1 пациент с передней верхней блокадой пучка Гиса и 1 пациент с синусовой аритмией.

В нашем исследовании было обнаружено, что уровень холестерина ЛПВП в сыворотке крови у пациентов с тяжелой формой COVID-19, осложненной сердечно-сосудистыми заболеваниями (СС3), значительно ниже, чем у пациентов с нетяжелой формой COVID-19, осложненной CC3. Антиатеросклеротический холестерин (HDL-C) является маркером атеросклероза и одним из фракторов прогнозирования сердечно-сосудистых событий. Холестерин ЛПВП может влиять на рецепторы клеточной поверхности и клетки иммунной функции. Крупномасштабное популяционное когортное исследование [6] показывает, что уровень ЛПВП связан с более высоким риском инфекции и предполагает, что ЛПВП также играет важную роль в иммунном ответе. Это открытие указывает на то, что сердечно-сосудистые события, связанные с патологией коронарной артерии, могут ускорить прогрессирование заболевания COVID-19.

\section{COVID-19 И ДЫХАТЕЛЬНАЯ СИСТЕМА}

Как описано в Плане диагностики и лечения пневмонии, вызванной новым коронавирусом (COVID-19) (версия 7, исследование), частота возникновения нарушений функции дыхания у пациентов с нетяжелой формой COVID-19 составляет до 70\%, а у выписанных пациентов с тяжелой формой COVID-19 может достигать 100\%; 80\% выписанных пациентов по-прежнему испытывают одышку после занятий.

В острой стадии COVID-19 характеризуется множественными и многосегментными тенями в виде матового стекла и тенью пятен консолидации, а некоторые поражения похожи на изменения, подобные организующей пневмонии. У тяжелых пациентов наблюдается диффузная тень матового стекла. Патология образцов трупного легкого и патология аутопсии предполагают диффузное альвеолярное повреждение (ДАП). Сетчатые тени и тракционные бронхоэктазы могут быть замечены в период восстановления, остаются фиирозные изменения легких, а у некоторых пациентов наблюдаются изменения, подобные обычной интерстициальной пневмонии (идиопатическому легочному фиброзу).

Ранними изменениями на КТ-изображениях легких в основном являются матовое стекло, экссудация, утолщение междольковых перегородок и т.д.; более поздние симптомы - в основном уплотнения и кровотечение; на стадии выздоровления они могут полностью рассасываться и исчезать, либо восстанавливаться после фиброза.

Визуализация изменений на стадии осложнений может выявить фиброз и уменьшение объема легких. Однако в настоящее время у нас все еще нет отдаленных результатов наблюдений. В настоящее время у нас есть только 2-месячный опыт наблюдения, результаты долгосрочного наблюдения еще не получены.

КТ грудной клетки пациентов с развившейся пневмонией характеризуется появлением двусторонних очагов матового стекла, расположенных в субплевральных областях легких, и прогрессирующими поражениями, которые приводят к консолидации без мигрирующих очагов. Плевральный выпот и лимфаденопатия средостения встречаются редко. Поскольку у пациентов могут быть воспалительные изменения в легких наряду с отрицательным ранним ПЦР-тестом на нуклеиновую кислоту, то КТ грудной клетки в сочетании с эпидемиологическими и лабораторными исследованиями является полезным обследованием для оценки заболевания и лечебного эффректа [7].

Когда все респираторные симптомы исчезали, консолидация легких на КТ-изображениях грудной клетки отсутствовала, а анализ мазков из горла с помощью ПЦР-теста на вирус SARS-CoV-2 был отрицательным; эти пациенты могли вернуться к нормальной социальной жизни. Подавляющее большинство пациентов не имеют рецидивов COVID-19. У них нет симптомов лихорадки, боли в горле и одышки. Трехнедельное наблюдение показало, что исчезают все симптомы кашля, а на снимках видно излечение пораженных легких. Соответствующие исследования, проведенные в Китае, показывают, что только у 7,7\% пациентов рецидивы наблюдаются в фразе карантина и в фазе наблюдения.

Наблюдение в течение почти 1-3 мес за более чем 10 пациентами с COVID-19 в нашей больнице показало: на КТ-изображениях грудной клетки поражения у всех пациентов в значительной степени рассосались (рисунок), по сравнению с предыду- 
щими снимками, и не сопровождались лихорадкой, диареей и респираторные симптомами.

У большинства пациентов с COVID-19 наблюдаются только легкие симптомы или симптомы отсутствуют. Однако, как только у этих пациентов развивается серьезная дыхательная недостаточность, связанная с интерстициальной пневмонией и острым респираторным дистресс-синдромом, вероятность смерти у них повышается. В настоящее время фракторы риска дыхательной недостаточности включают пожилой возраст, осложнения основных заболеваний (например, гипертонию, диабет, хроническое воспалительное заболевание дыхательных путей и т.д.), иммуносупрессию и т.п. Китайские ученые отметили, что пациенты с группой крови A имеют более высокую заболеваемость COVID-19, чем пациенты с другими группами крови, в то время как пациенты с группой крови 0 имеют более низкую вероятность COVID-19, чем пациенты с другими группами крови. Последние исследования из Норвегии и Германии, опубликованные в Медицинском журнале Новой Англии (NEJM), мощном международном медицинском журнале, также показывают, что группа крови связана с интенсивностью симптомов COVID-19. В частности, пациенты с COVID-19 с группой крови А имеют более высокий риск дыхательной недостаточности, чем пациенты с другими группами крови; в то время как группа крови 0 имеет более низкий риск дыхательной недостаточности, чем другие. Следовательно, группа крови 0 может иметь защитные функции.

\section{COVID-19 И TРОМБОЗ}

3.1. У многих ли пациентов с COVID-19 выявлена тромбоэмболия легких и тромбоз глубоких вен?

По данным литературы, частота тромбозов глубоких вен нижних конечностей при COVID-19 составляет около 46,1\% (66/143 случаев) [8]. Недавно китайские ученые сообщили о скрининге и клиническом исследовании тромбоза глубоких вен нижних конечностей у 48 критических пациентов с COVID-19 в отделении интенсивной терапии (ОИT). Среди них 47 пациентов получали антикоагулянтную терапию путем подкожной инъекции низкомолекулярного гепарина один раз в день. Однако у $85,4 \%$ этих пациентов (41/48 случаев) по-прежнему был тромбоз глубоких вен, из них в 36 (75\%) случаях он был локализован в дистальной вене, а в 5 (10,4\%) случаях - в проксимальной вене. Пациенты с осложненной молниеносной эмболией легочной артерии составляли около $10 \%$ (8/80), в то время как процент пациентов с эмболией периферической легочной артерии составлял 11,3\% (9/80) [9], частота эмболии легочной артерии составляла примерно 13,6\% (25/184) [10].

В ретроспективном исследовании 214 госпитализированных пациентов с COVID-19 из Ухани (Китай) 5,7\% тяжелых пациентов перенесли инсульт [11]. Новой особенностью тяжелых пациентов с COVID-19 является коагулопатия, называемая «коагулопатия, вызванная сепсисом» (SIC), с высоким уровнем D-димера и фибриногена. Приблизительно у $50 \%$ пациентов наблюдался повышенный уровень D-димера во время прогрессирования болезни, а доля смертей достигала 100\%. Повышение уровня D-димера у тяжелых пациентов является важной причиной инсульта. Из-за лежания в постели, ожирения, преклонного возраста, тромбофилии и других факторов риска у этих пациентов выше вероятность инсульта, вызванного состоянием гиперкоагуляции. Таким образом, в профилактике, контроле и лечении COVID-19 нельзя игнорировать звено антикоагулянтной терапии.

Для всех тяжелых и критически больных пациентов с COVID-19, а также легких и среднетяжелых пациентов, которые имеют более высокий риск в отношении тромбозов, при отсутствии противопоказаний, рекомендуется назначать антикоагулянтную терапию, а антикоагулянты должны быть парентеральными. Больным с нарушениями свертываемости крови рекомендуется использовать нефракционированный гепарин/низкомолекулярный гепарин для снижения потребления возможной антикоагулянтной терапии субстратом коагуляции. Тромболитическая терапия рекомендуется пациентам с клинической острой тромбоэмболией легочной артерии высокого риска.

3.2. Какова дозировка низкомолекулярного гепарина для стационарных пациентов c COVID-19 средней и тяжелой степени тяжести?

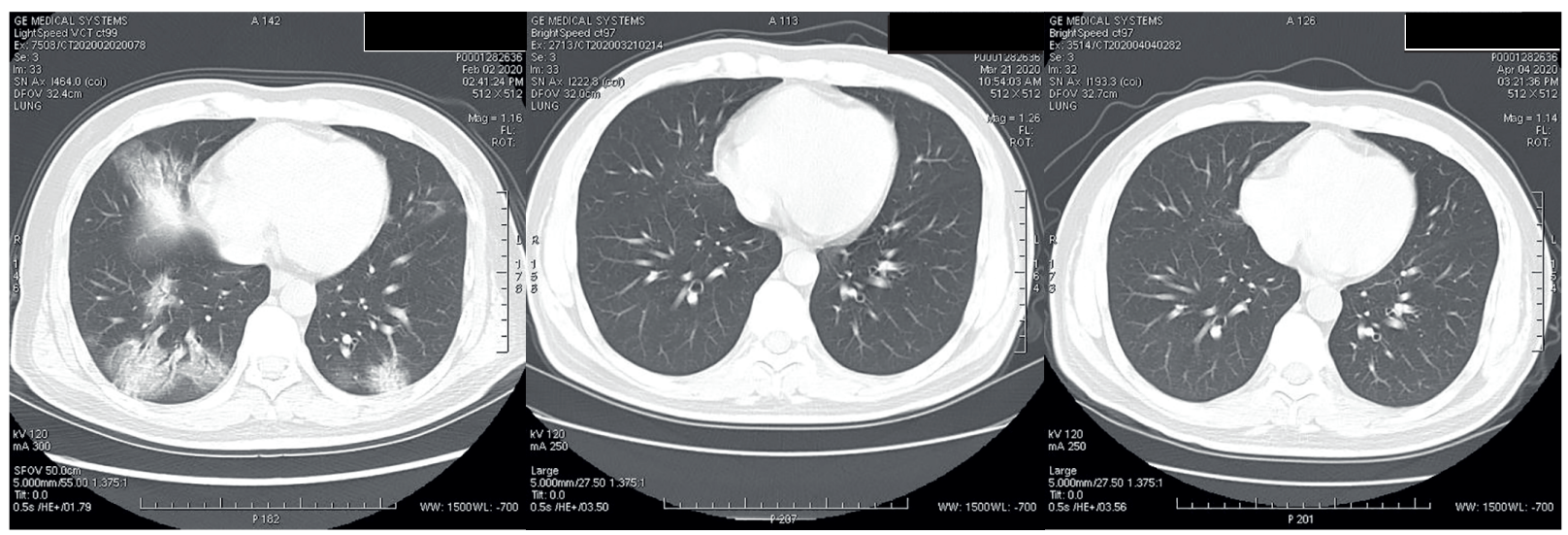

Данные компьютерной томографрии одного из больных COVID-19 
Сообщалось, что среди 449 пациентов с тяжелой формой COVID-19 инъекция низкомолекулярного гепарина (40-60 мг/день, непрерывно более 7 дней, 99/449 случаев) не снизила 28-дневную смертность пациентов, но может эффективно улучшить показатель коагулопатии, вызванной сепсисом (оценка SIC). Недавно китайские ученые сообщили о скрининге и клиническом исследовании тромбоза глубоких вен нижних конечностей у 48 критических пациентов с COVID-19 в отделении интенсивной терапии. Среди них 47 пациентов получали антикоагулянтную терапию путем подкожной инъекции низкомолекулярного гепарина один раз в день. Однако у 85,4\% этих пациентов (41/48 случаев) по-прежнему был тромбоз глубоких вен, из которых в 36 (75\%) случаях он был локализован в дистальной вене, а в $5(10,4 \%)$ случаях - в проксимальной вене. Это указывает на необходимость дальнейшего изучения дозировки низкомолекулярного гепарина для пациентов с COVID-19 средней и тяжелой степени [12].

\section{4. ИММУННЫЙ СТАТУС ЛЮДЕЙ ПРОТИВ COVID-19}

После заражения дыхательной системы COVID-19 у пациентов наблюдаются жар, кашель и другие симптомы. Затем, после получения усиленного сигнала интерферона в патологических условиях, естественные клетки-киллеры врожденной иммунной системы человека активируются и начинают устранять инфицированные вирусом клетки и препятствовать амплификации нового коронавируса. Так работает врожденная иммунная система человека на ранней стадии (1-4 дня). Если у пациентов есть сильная иммунная функция, то на этой стадии можно контролировать амплификацию вируса; большинство из них - пациенты с легкой или обычной фрормой заболевания.

Если врожденная иммунная система не может контролировать такую амплификацию на ранней стадии, то адаптивный иммунный ответ позволяет генерировать специфические цитотоксические Т-клетки, индуцированные новым коронавирусом, и убивать клетки, инфицированные новым коронавирусом. В то же время В-лимфоциты индуцируются протеантигеном нового коронавируса, чтобы секретировать специфические антитела против нового коронавируса и уничтожать вирусы. В то время как вирусы удаляются, дыхательные пути и эпителиальная ткань легочных альвеол тоже повреждаются. Поэтому возникают пневмония, поражение дыхательных путей и другие симптомы. Чем выше уровень репликации вируса, тем больше вероятность того, что это вызовет чрезмерное возбуждение иммунной системы - «цитокиновый шторм» - и легко приведет к полиорганной недостаточности.

\section{COVID-19 У БЕРЕMЕННЫХ И РОЖЕНИЦ}

В профилактике инфекционных заболеваний и борьбе с ними двумя наиболее важными звеньями являются разрыв пути передачи и защита уязвимого населения, а беременные и роженицы являются уязвимыми группами. По этой причине больница и каждое отделение приняли экстренные меры, такие как определение лечебных процедур и предоставле- ние знаний о COVID-19 беременным и роженицам через средства массовой информации.

Ни одна беременная женщина с инфекцией COVID-19 не была госпитализирована в нашу больницу, а у новорожденных внутриутробной инфекции не наблюдалось. Имеющиеся внутренние и международные данные свидетельствуют о том, что вертикальной передачи инфекции от матери к ребенку может не быть. Опубликован доклад академика Цяо Цзе. В Медицинском журнале Новой Англии проанализированы клинические характеристики 118 случаев заражения COVID-19 беременных и рожениц в Ухане (Китай), из которых 68 родили 70 новорожденных; тесты на нуклеиновую кислоту SARS-CoV-2 проводились с помощью мазка из зева у 8 новорожденных и проб грудного молока в 3 случаях, все результаты были отрицательными [13]. В другом исследовании, опубликованном в Американском журнале акушерства и гинекологии, были обобщены зарегистрированные случаи; 48 новорожденных прошли тест на нуклеиновую кислоту, из которых только 2 теста были положительными, а у 46 беременных и рожениц, инфицированных COVID-19, их околоплодные воды, пуповинная кровь, грудное молоко и мазок из горла младенцев не имели вируса COVID-19, но не следует исключать, что эти женщины и роженицы с подтвержденным вирусом были инфицированы на более поздней стадии беременности, и нет сообщений о выкидышах у беременных, инфицированных COVID-19 на ранней стадии [14].

Хотя нет никаких доказательств вертикальной передачи плоду от плаценты, предыдущие исследования на животных показали, что вирусные инфекции во время беременности могут вызывать аномалии в развитии мозга и легких плода. Инфекция COVID-19 может активировать материнскую иммунную систему, а затем генерировать множество цитокинов, таких как IL-6, которые через воспалительную реакцию плаценты вызывают синдром воспалительной реакции плода и, кроме того, приводят к повреждению органов и потенциальным дефектам развития.

Поскольку риск вертикальной передачи инфекции от матери к ребенку не ясен, а осложнения, связанные с беременностью, вызванные COVID-19, также неизвестны, мы не можем вслепую проводить экспериментальное лечение этой особой группы беременных и рожениц. Клинически гидроксихлорохин используется для лечения повторного выкидыша (с дозировкой около 300 мг/день), тогда как при противовирусном лечении минимальная доза составляет 1000 мг/день, что намного выше, чем при других методах лечения, и хлорохин, и его метаболиты могут пройти через плаценту, поэтому необходимо учитывать дозировку при применении этих препаратов у беременных. По нашему мнению, не рекомендуется принимать препараты беременным женщинам до тех пор, пока не будет доказано, что антитела COVID-19 безопасны для противовирусного лечения. 


\section{6. ПРИМЕНЕНИЕ ПЛАЗМЫ ВЫЗДОРОВЕВШИХ ПАЦИЕНТОВ}

6.1. Когда для критических пациентов лучше всего использовать плазму выздоравливающих пациентов?

Пациентам без серьезных осложнений и пациентам с быстрым прогрессом заболевания плазму лучше использовать раньше, чем позже. Пациенты, у которых не улучшилось состояние после недели противовирусного лечения, могут получать плазму от выздоравливающих пациентов. Дозировка составляет 200-400 мл/раз/день, 2-3 раза подряд для большинства пациентов или полная доза 400 мл только один раз.

6.2. Какие лабораторные методы можно использовать для проверки клинического лечебного эффекта плазмы выздоравливающих пациентов?

Некоторые лабораторные методы могут использоваться для оценки клинического лечебного эффекта плазмы выздоравливающих пациентов. Снижена ли вирусная нагрузка (если можно провести тест на нейтрализацию вирусов)? Увеличено ли значение СТ для обнаружения вирусных нуклеиновых кислот (ПЦР)? Облегчены ли клинические симптомы, в том числе увеличивается ли насыщение оксигемоглобином? Показывает ли компьютерная томография, что экссудация легких значительно рассасывается?

6.3. Вопросы о донорстве плазмы от выздоравливающих пациентов

Пациенты с COVID-19, выписанные из больницы через 2 нед (два отрицательных теста на нуклеиновые кислоты), должны пройти тест на антитела COVID-19 с помощью набора флуоресценции (предоставляется WANTAI BioPharm, Пекин), после чего они могут сдать плазму, чтобы тестировать на антитела COVID-19, IgM и общие антитела; титр должен быть не менее 1:80. Плазму собирают аппаратом для плазмафереза и замораживают при $\mathrm{T}-20^{\circ} \mathrm{C}$ для хранения. Переливание допускается при одинаковой группе крови или совместимости.

\section{7. МЕДИКАМЕНТОЗНАЯ ТЕРАПИЯ}

\section{1. Антибактериальная терапия}

Пациенты c COVID-19 легкой степени и общими симптомами имеют относительно более низкую частоту вторичной бактериальной инфекции, поэтому рутинная антибактериальная терапия не рекомендуется для таких пациентов. В случае постоянной лихорадки или повторной лихорадки после того, как температура тела станет нормальной, плановое исследование крови следует проводить чаще; должны быть проверены воспалительные признаки, такие как СРБ, ПКТ, должно быть выполнено компьютерное сканирование легких. Если есть какие-либо признаки вторичной инфекции, можно добавить антибиотики, которые можно использовать отдельно. Предпочтительны препараты, действующие на отрицательные бактерии.

Пациенты с тяжелым или критическим течением COVID-19 склонны к вторичной бактериальной инфекции с длительным сроком госпитализации, нарушенной иммунной системой и ранним использованием гормонов для блокирования цитокиновых бурь.
Этим пациентам следует часто проводить рутинный анализ крови, тесты на метки воспаления, такие как СРБ, ПКТ, G-тест и GM-тест, а также компьютерную томографию легких. Если есть какие-либо признаки вторичной инфекции, можно добавить антибиотики. Вначале можно использовать только более сильные препараты, действующие на отрицательные бактерии, а препараты с плохим эффектом или при тяжелых заболеваниях можно комбинировать с лекарствами от положительных бактерий. Противогрибковые препараты можно комбинировать при наличии признаков и проявлений грибковой инфекции.

Пациентам с COVID-19 в легкой форме не рекомендуется лечение или профилактика антибиотиками. Предполагается, что антибиотики не должны использоваться пациентами с подозрением или подтвержденным умеренным COVID-19, если у них нет клинического подозрения на бактериальную инфекцию. Следует отметить, что тяжелые пациенты часто болеют в течение 5-7 дней и более, и есть много причин подавления клеточного иммунитета, особенно у тех, кто нуждается в инвазивной искусственной вентиляции легких в отделении интенсивной терапии, нужно обращать внимание на вторичные бактериальные или грибковые заболевания. Если это обосновано, то следует контролировать респираторные патогены и проводить специфическую противоинфекционную терапию. Если пациенты в анамнезе применяли антибиотики менее 90 дней, находились в больнице более 72 ч или страдали от ранее перенесенного легочного заболевания, рекомендуется использовать антибиотики, действующие на лекарственно-устойчивые бактерии.

7.2. Когда целесообразнее назначать пациентам противомалярийные препараты?

Роль хлорохина в лечении COVID-19 остается спорной [15]. Проспективное исследование было выполнено у 30 китайских пациентов [16]. Эти пациенты были рандомизированы в группу гидроксихлорохина + стандартное лечение (включая поддерживающую терапию, интерферон и другие противовирусные препараты) и группу стандартного лечения (1:1). Группа гидроксихлорохина + стандартное лечение получала 400 мг гидроксихлорохина каждый день в течение 5 дней; результаты показали отсутствие статистической разницы.

B мае 2020 г. NEJM опубликовал результат большого выборочного обсервационного исследования «Наблюдательное исследование гидроксихлорохина у госпитализированных пациентов с COVID-19» [17]. Исследователи изучили корреляцию между пациентами c COVID-19, получающими лечение гидроксихлорохином, и интубацией или смертью в крупном медицинском центре в Нью-Йорке. Среди 1376 пациентов, включенных в это исследование, $346(25,1 \%)$ пациентов страдали дыхательной недостаточностью, из которых 180 человек были интубированы, 166 умерли без интубации. При грубом анализе у пациентов, которые принимали гидроксихлорохин, вероятность достижения основного конечного результата была выше, чем у тех, кто его не принимал. Многофакторный анализ, основанный на выявлении тенденций, показал, что не было 
значительной корреляции между приемом гидроксихлорохина и конечной точкой исследования. Кроме того, не было значительной корреляции между азитромицином и конечной точкой исследования.

7.3. Какие средства и лекарства эффективны при лечении тяжелых и критических пациентов?

B условиях эпидемии COVID-19 в Китае никакие препараты с явным противовирусным действием не смогли способствовать избавлению от вируса. При клиническом лечении арбидол, хлорохин/гидроксихлорохин применяли перорально, а интерферон вдыхали путем распыления. Данные китайских врачей частично показали, что раннее предупреждение и краткосрочное применение низких доз гормона для критических пациентов может снизить процент критических случаев и уровень летальности. Пациентам, у которых наступила критическая стадия, вводят плазму выздоровевших, проводят лечение по очистке крови и иммунотерапию на основе обычного лечения. Эти методы лечения до некоторой степени эфффективны, но нет проспективных рандомизированных контролируемых исследований, подтверждающих их. Крупномасштабное клиническое испытание в Великобритании продемонстрировало, что использование глюкокортикоидов может снизить смертность от COVID-19 [18]. В исследовании RECOVERY было более 11000 пациентов из 175 больниц, входящих в Национальную систему здравоохранения. Предварительные данные показывают, что 2100 пациентов, набранных с марта по июнь, получали дексаметазон от средней до низкой дозы (6 мг) в течение 10 дней подряд. Результаты лечения сравнивали с результатами лечения 4300 пациентов, которые прошли стандартную терапию против инфекции COVID-19. Результаты показывают, что дексаметазон дает наилучшие результаты для тяжелых пациентов, которым необходимо использовать аппарат ИВЛ, поскольку смертность снижается на 1/3; тем, кому нужна ингаляция кислорода, а не ИВЛ, улучшается состояние после приема лекарств, и риск их смертности снижается на $20 \%$.

Хотя арбидол широко применялся во время эпидемии COVID-19 в Китае, нет рандомизированного контролируемого исследования для проверки его эфффективности. Нерандомизированное исследование 67 пациентов с COVID-19 показало, что лечение арбидолом со средним курсом 9-дневного лечения было связано с более низкой смертностью и более высокой частотой выписки по сравнению с пациентами, которые не принимали препарат [19]. Однако эти данные не могут определить эффективность арбидола против COVID-19. Для дальнейшей оценки этого препарата следует провести РКИ. Осельтамивир, ингибитор нейраминидазы, был одобрен для использования при лечении гриппа, но не было обнаружено сообщений об активности против SARS-CoV-2 in vitro. Поэтому не рекомендуется его рассматривать как меру вмешательства. После исключения гриппа этот препарат не эффективен при лечении COVID-19.

\section{4. Антиинтерлейкиновые препараты} в лечении COVID-19
Согласно Руководству по диагностике и лечению COVID-19 в Китае (7-е изд.) препараты Канг-ИЛ используются в основном для подавления «цитокинового шторма». В настоящее время терапия Канг ИЛ-6 чаще используется в клинической практике в Китае. Например, принимая тоцилизумаб, он подходит для лечения пациентов с обширными поражениями легких и пациентов в критическом состоянии. Кроме того, тоцилизумаб можно применять для лечения пациентов с повышенным уровнем ИЛ-6, выявленным в лабораторных исследованиях. Способ применения: первая доза составляет 4-8 мг/ кг, рекомендуемая доза - 400 мг, разбавленная до 100 мл 0,9\% фризиологическим раствором. Переливание длится более 1 часа. Максимальная разовая доза не должна превышать 800 мг, при этом следует обращать внимание на аллергическую реакцию.

7.5. Систематическое использование кортикостероидов

Доступные нам исследования показали, что системные глюкокортикоиды не должны рутинно использоваться для лечения вирусной пневмонии. Систематический обзор и метаанализ эффектов лечения глюкокортикоидами на прогноз пациентов c SARS-CoV-2, SARS-CoV и MERS-CoV показал, что глюкокортикоиды незначительно снижали риск смерти, время госпитализации и частоту госпитализаций в реанимацию и использования искусственной вентиляции легких. Систематический обзор обсервационного исследования использования кортикостероидов у пациентов с SARS не выявил преимуществ выживаемости и возможных опасностях (аваскулярный некроз головки бедренной кости, диабет и замедленное выведение вируса). Систематический обзор наблюдательных исследований гриппа показал, что смертность и риск вторичной инфекции были выше при использовании кортикостероидов. Пациентам с обострением хронической обструктивной болезни легких (ХОБЛ) необходимо назначать глюкокортикоиды в соответствии с их специфическими симптомами.

План диагностики и лечения тяжелых и критических случаев COVID-19 (испытание, 2-е изд.). В настоящее время нет медицинских доказательств, подтверждающих применение глюкокортикоидов для улучшения лечения COVID-19. Тем не менее для пациентов с прогрессирующим ухудшением индекса оксигенации, быстрым прогрессом визуализации и чрезмерной активацией воспалительной реакции рекомендуется кратковременное лечение метилпреднизолоном (40 мг, каждые 12 ч, в течение 5 дней). Перед этим следует проанализировать противопоказания на гормоны. При этом необходимо внимательно следить за изменениями артериального давления и глюкозы в крови пациентов.

\section{8. ПОСЛЕДСТВИЯ COVID-19}

Повреждение легких: в основном проявляется как одышка при ходьбе в быстром темпе, невозможность выполнять обычные упражнения и даже невозможность вернуться к предыдущей работе. У некоторых тяжелых пациентов после излечения может развиться фриброз легких, что может ограничивать их повседневную жизнь. В настоящее время 
не существует специальных лекарств для лечения фриброза легких, и это состояние необратимо.

Повреждение печени и почек: исследования показали, что поражение почек часто встречается у людей, инфицированных COVID-19.

Повреждение головного мозга: многие выздоравливающие пациенты страдают очень серьезными последствиями для центральной нервной системы. В основном есть три типа симптомов:

1) симптомы со стороны центральной нервной системы, такие как головная боль, головокружение, нарушение сознания, острое цереброваскулярное заболевание, эпилепсия и т.д.;

2) симптомы периферической нервной системы, такие как гипогевзия, гипосмия, анорексия, невралгия и т.д.;

3) мышечное повреждение.

Кроме того, у многих бессимптомных носителей есть такие последствия, как тромбоз, проникающий в кровеносный сосуд головного мозга, что в конечном итоге приводит к инсульту.

Повреждение сердца: исследователи обнаружили, что при опросе 8000 пациентов, инфицированных COVID-19, более половины тяжелобольных пациентов пострадали от поражений сердца, а некоторые из них даже умерли. Осложнения более серьезны, особенно у пациентов с COVID-19, которые использовали аппарат искусственной вентиляции легких.

Сокращение продолжительности жизни: согласно исследованию, проведенному шотландским ученым, тяжелобольные пациенты, инфицированные COVID-19, теряют в среднем 12-14 лет жизни после излечения из-за атаки вируса на различные органы; продолжительность жизни, сокращенная из-за COVID-19, аналогична продолжительности жизни при тяжелых заболеваниях, таких как болезнь сердца или тяжелое респираторное заболевание. Конечно, это исследование подвергается сомнению многими исследователями и предполагает, что последствия COVID-19 могут быть более серьезными, чем мы думали.

\section{COVID-19 КОНТРОЛЬ И ПРОФИЛАКТИКА: ОПЫТ БОЛЬНИЦЫ В ОБЛАСТИ БОРЬБЫ С ИНФЕКЦИЯМИ}

Контроль и профрилактика COVID-19 - это управление инфекциями и их профилактика. Опыт больницы основан на принципе «изолировать источник инфекции, отрезать путь передачи и защитить уязвимое население». Основными путями передачи COVID-19 являются воздушно-капельная и контактная. Существует возможность передачи аэрозоля (замкнутая среда, длительное время, высокая концентрация). Поскольку COVID-19 можно обнаружить через фрекалии и мочу, следует обратить внимание на аэрозольную или контактную передачу при загрязнении окружающей среды фекалиями и мочой. Пути распространения инфекции еще предстоит выяснить. Источником инфекции в основном являются пациенты, инфицированные COVID-19. Источником инфекции также может быть бессимптомный носитель. Люди, как правило, восприимчивы.
Установлено, что вирус может выжить в течение 3 ч в аэрозоле (при температуре $21-23^{\circ} \mathrm{C}$ и относительной влажности 65\%), не менее 4 ч на медной поверхности, в течение 24 ч в картонной упаковке. На поверхности из нержавеющей стали и пластика (при температуре $21-23^{\circ} \mathrm{C}$ и относительной влажности воздуха 40\%) может сохраняться в течение 2-3 дней. COVID-19 чувствителен к ультрафиолету и теплу и может эффрективно инактивироваться при температуре $56^{\circ} \mathrm{C}$ в течение 30 мин, чувствителен к диэтиловому эфиру, 75\% этиловому спирту, хлорсодержащему дезинфицирующему средству, надуксусной кислоте и хлорофрорму.

План диагностики и лечения COVID-19 в нашей стране пересматривался 7 раз, используя известные на данный момент этиологические характеристики COVID-19 и улучшенные на основе существующих систем стандарты и нормы по профилактике и контролю инфекций в медицинских учреждениях. Техническое руководство уделяет больше внимания практике и руководству. Благодаря строгому соблюдению Технического руководства более 42000 медицинских работников, обслуживающих Ухань по всей стране, не заразились инфекциями.

Техническое руководство включает четыре аспекта: І. Основные требования. II. Управление ключевыми департаментами. III. Защита медицинского персонала. IV. Усиление управления пациентами.

Основные требования включают разработку плана действий в чрезвычайных ситуациях и составление плана рабочего процесса, обучение всех рабочих и персонала, защиту медицинского персонала, медицинское обслуживание медицинского персонала, усиленный надзор за инфекциями, управление очисткой и дезинфекцией, управление и обучение пациентов, управление вспышками инфекций и медицинскими отходами. Управление ключевыми отделениями включает лихорадочную клинику и амбулаторное лечение, отделение неотложной помощи, стационарное отделение (палату) для приема и лечения подозреваемых или подтвержденных пациентов и общую палату. Медицинский персонал принимает меры по изоляции капель, контактов и воздушной изоляции для достижения защиты. Уделяя внимание управлению пациентами и медицинским персоналом, больница должна научно и разумно сформулировать процесс проверки всего персонала в соответствии с условиями работы другого персонала, чтобы персонал не стал источником завозной инфекции.

Прозрачность исследования. Исследование не имело спонсорской поддержки. Авторы несут полную ответственность за предоставление окончательной версии рукописи в печать.

Декларация о финансовых и других взаимоотношениях. Все авторы принимали участие в разработке концепции, дизайна исследования и в написании рукописи. Окончательная версия рукописи была одобрена всеми авторами. Авторы не получали гонорар за исследование. 


\section{ЛИТЕРАTУPA / REFERENCES}

1. Cardiac Implications of Novel Wuhan Coronavirus (COVID-19 ). ACC Clinical Bulletin (2020). https://www. dicardiology.com/article/cardiac-implications-novelcoronavirus

2. Li B, et al. Prevalence and impact of cardiovascular metabolic diseases on COVID-19 in China. Clin Res Cardiol. 2020; 109: 531-538. doi:10.1007/s00392-02001626-9 (2020)

3. Huang $\mathrm{C}$, et al. Clinical features of patients infected with 2019 novel coronavirus in Wuhan, China. Lancet. 2020; 395: 497-506. doi:10.1016/S0140-6736(20)30183-5 (2020)

4. Guo T, et al. Cardiovascular Implications of Fatal Outcomes of Patients With Coronavirus Disease 2019 (COVID-19). JAMA Cardiol. 2020. doi:10.1001/jamacardio.2020.1017 (2020).

5. Wang D, et al. Clinical Characteristics of 138 Hospitalized Patients With 2019 Novel Coronavirus-Infected Pneumonia in Wuhan, China. JAMA. 2020. doi:10.1001/ jama.2020.1585 (2020).

6. Deng $Q$, et al. Suspected myocardial injury in patients with COVID-19: Evidence from front-line clinical observation in Wuhan, China. Int J Cardiol. 2020; 311: 116-121. doi:10.1016/j.jijcard.2020.03.087

7. Zhao X, Liu B, Yu Y, et al. The characteristics and clinical value of chest $\mathrm{CT}$ images of novel coronavirus pneumonia. J Clin Radiol. 2020; 75: 335-340.

8. Zhang L, et al. Deep Vein Thrombosis in Hospitalized Patients with Coronavirus Disease 2019 (COVID-19) in Wuhan, China: Prevalence, Risk Factors, and Outcome. Circulation. doi:10.1161/CIRCULATIONAHA.120.046702

9. Edler $\mathrm{C}$, et al. Dying with SARS-CoV-2 infection-an autopsy study of the first consecutive 80 cases in Hamburg, Germany. Int J Legal Med. 2020; 134: 1275-1284. doi:10.1007/s00414-020-02317-w

10. Boccia M, et al. COVID-19 and coagulative axis: review of emerging aspects in a novel disease. Monaldi Arch Chest Dis. 2020; 90: doi:10.4081/monaldi.2020.1300
11. Li Yanan, Li Man, Wang Mengdie, et al. Acute cerebrovascular disease following COVID-19: a single center, retrospective, observational study. J Stroke Vasc Neurol. 2020. https://www.researchgate.net/ publication/340154622_Acute_Cerebrovascular Disease_Following_COVID-19_A_Single_Center_ Retrospective_Observational_Study

12. Tang $\mathrm{N}$, et al. Anticoagulant treatment is associated with decreased mortality in severe coronavirus disease 2019 patients with coagulopathy. J Thromb Haemost. 2020; 18: 1094-1099. doi:10.1111/jth.14817

13. Chen L, Li Q, Zheng D, et al. Clinical Characteristics of Pregnant Women with Covid-19 in Wuhan, China. J N Engl J Med. 2020; 382 (25): e100.

14. Dashraath P, Wong JLJ, Lim MXK, et al. Coronavirus disease 2019 (COVID-19) pandemic and pregnancy. J Am J Obstet Gynecol. 2020; 222 (6): 521-531.

15. Mégarbane Bruno. Chloroquine and hydroxychloroquine to treat COVID-19: between hope and caution.J Clin Toxicol (Phila). 2020; undefined: 1-2.

16. Chen J. A pilot study of hydroxychloroquine in treatment of patients with common coronavirus disease-19 (COVID-19). Journal of Zhejiang University. 2020; 10089292. doi: 10.3785/j.issn.10089292.2020.03.03

17. Geleris Joshua, Sun Yifei, Platt Jonathan, et al. Observational Study of Hydroxychloroquine in Hospitalized Patients with Covid-19. J N Engl J Med. 2020; 382: 24112418.

18. RECOVERY Collaborative Group, Horby Peter, Lim Wei Shen, et al. Dexamethasone in Hospitalized Patients with Covid-19 - Preliminary Report. J N Engl J Med. 2020; NEJMoa2021436. doi: 10.1056/NEJMoa2021436.

19. Chen Wenyu, Yao Ming, Fang Zhixian, et al. A study on clinical effect of Arbidol combined with adjuvant therapy on COVID-19. J Med Virol. 2020; doi:10.1002/jmv.26142. 